\title{
Exploring the symbolic meaning of usership
}

\author{
Wie können sich Menschen mit Waren identifi- \\ zieren, wenn diese verstärkt nur als Dienstleis- \\ tungen angeboten werden? Die zeitlich be- \\ grenzte Nutzung von Waren, und nicht deren \\ Besitz zieht weitreichende Folgen für Anbieter \\ und Benutzer nach sich. \\ Von Gerd Scholl
}

\begin{abstract}
roduct service systems (PSS) have been one major concern of research into sustainable consumption for more than ten years. They can be divided into services providing added value to the product life cycle, such as maintenance and up-grading, services providing enabling platforms for customers, such as product sharing or renting, and services providing final results to the customers, such as mobility services or warmth delivery. In this paper, we will focus on the last two categories - denotable as "usership", which is "all types of consumption in which the consumer does not possess legal title to the product" (Obenberger Brown 1976: 82).

When the discussion on PSS emerged, a functional or utilitarian perspective on usership prevailed. Products were regarded as "Dienstleistungserfüllungsmaschinen" and from this point of view, the main service delivered by a car, for instance, is to take you from one place to another (Schmidt-Bleek 1994: 179). This perspective ignores, however, that people consume goods and services not only for their functional properties. Symbolic qualities play a vital role when people buy and consume goods as well.
\end{abstract}

\section{The symbolic meaning of consumption}

Products can be regarded as "symbols for sale" (Levy 1959). They contribute to the construction of our modern culturally constituted societies “(...) because they are vital and tangible record of cultural meaning that is otherwise intangible" (McCracken 1986: 73). In late capitalism these construction patterns have become more complex and more subtle, so that goods have increasingly transformed to material containers of social ambitions and mobility. The symbolic meaning of consumption items plays an essential role in creating and maintaining personal and social identities.

People articulate their identities not solely, but also through their material possessions. Hence, ownership is strongly tied to a specific symbolic meaning contained in and conveyed through the material artefacts possessed. But what will happen to this symbolic meaning, when we turn from ownership to usership? In order to shed light upon this question we first draw attention to selected facets of the symbolic roles of possessions and then address the symbolic meanings conveyed in usership.

\section{The symbolic meaning of ownership}

There is plenty of evidence that possessions may serve as symbols of control. Hunt et al., for instance, have shown that individuals who believe life is a product of external forces rather than a result of personal endeavours, more often tend to have materialistic attitudes, that often go hand in hand with a tendency to maintain ownership of one's possessions (1990: 1102). Furby has shown in a number of studies that ownership is an expression of a person's ability to control the environment (1978: 319). And Belk argues that people regard material objects as part of their "extended self" to the extent in which they are able to exercise control over them (1988: 140).

Since self-perception of an individual is, amongst others, dependent on the achieved locus within the social hierarchy, status symbols are an essential part of the individual's identity. They work like "trophies" providing the owner with information about his or her accomplishments and they serve to maintain social order by visualising vertical differentiation among people. The assignment of status value to products has become a dynamic process, so that status validation increasingly turns to an "exercise in 'applied semiotics' (...) (in which) the status-conscious actor must engage in an ongoing quest to identify those specific consumption events that will successfully yield social honor" (Solomon 1999: 75).

The locatory function of possessions is not confined, however, to the vertical dimension of status. They may also serve to indicate membership to certain social groups. The various roles an individual adopts while acting in different social entities contribute to the manifestation of his or her self concept. As regards the meaning of material possessions in this process of self definition Laverie et al., for instance, found that a specific role identity is more important for shaping the individual's identity when more identity-relevant possessions are available to enact the identity well (2002: 668).

But what is - symbolically - left, when possessions have turned to a product service system, when your own car has been replaced by access to a car sharing fleet, when your own was- 
hing machine has been substituted by a launderette and/or a textile cleaning service, or when you have traded in your own pair of skis for the on-demand purchase of ski rentals?

\section{The nature of a service}

To answer this we first take a look at the very nature of services. In general, one can differentiate three dimensions of service production:

1. Service as a resource: This perspective focuses on the internal factors necessary to produce the service, such as facilities, infrastructure, machines, skills of the employees etc.

2. Service as a process: During the process of service delivery the internal factors are combined with the external factor, i.e. the customer.

3. Service as a result: This dimension stresses the result of the service delivery process. One can differentiate between a direct result, e.g., a fixed car, and an indirect result, e.g., recovery of the car owner's mobility.

In the following, we use this conceptualisation of services to identify possible service-related factors shaping the symbolic meaning of usership. We focus on two issues: the symbolic sense of control provocable in and through usership at an intrapersonal level and the categorical symbolic meaning that helps socially locating the individual at an interpersonal level.

\section{Intrapersonal symbolic meaning of usership}

A perceived lack of control influences the behaviour of the customer in the service encounter. It may be one important source of dissatisfaction with the service performance.

When moving from ownership to usership people give up their full control over the commercial good. To compensate for this confinement service resources should be designed so as to restore options of control for the customer. This can be achieved by maximising ease of access to the service offer, for instance, by means of flexible opening hours, online booking, and delivery services. Moreover, a sense of control can be rebuilt by extending the scope of the service offer. This may encompass various measures, such as increasing the amount of available rental goods to ensure that demand can be met properly, enlarging the variety of rental goods to enhance fit with customer needs, offering rental goods of superior quality that provide higher performance, etc.

When it comes to the process of service delivery the quality of the interaction between the employee and the customer is crucial for re-establishing symbolic control. Notwithstanding the huge variety of interaction modes in usership - think of a ski rental company or a nappy service - a competent and friendly appearance of the contact personnel represents a generic response to the perceived loss of control. Moreover, Smith and Houston found that customers transpose repeated service encounters into stereotyped mental scripts (1983). The scripts gui-

\section{"Users transpose repeated service encounters into stereotyped mental scripts, thus gaining cognitive control over the process of using the service."}

de customer's experience of the service and can be regarded as a strategy of cognitive control. Hence, matching the processes in the service encounter with the mental scripts of the customers may further enhance the perceived control of the process. One can conclude, that standardisation of the service process over time is another means to regain a sense of control in usership.

A similar effect might stem from the physical surrounding of the service. If customers perceive greater personal control in the "servicescape", the pleasure of the service experience is increased, and this in turn makes service entry more attractive to customers. Environmental dimensions, such as, for instance, clear signage and good ventilation, in combination with proper spatial layout and good functionality of the servicescape, may all contribute to perceptions of personal control.

Another factor possibly evoking a sense of symbolic control in usership is mastery of the object. In particular, in services providing enabling platforms it is vital that the goods delivered for temporary use are self-explanatory and easy to operate. In the case of complex items and also when customers are unfamiliar with the rental good, a clear design of the product and plain instructions, provided either by the personnel or by simple manuals, can avoid a perceived loss of control and help make customers master the object more quickly.

\section{Interpersonal symbolic meaning of usership}

Individuals express their social identities, amongst others, through acquisition and use of material possessions. By so doing they seek to locate themselves - and are located by others in social-material terms. Today, societies are built from several different lifestyles by which people communicate their identities to themselves and others and articulate which groups they (do not) belong to and what social position they occupy or strive for.

Shaping locatory symbolism in and through usership implies finding ways to better connect usership with the lifestyles of the envisaged target groups. This connection can be 
facilitated by a dedicated service brand. In general, a brand works as a symbolic resource carrying or portraying a set of social meanings associated with the consumption of the branded good. From the customer's point of view, a brand provides orientation, generates trust, and conveys prestige. From the supplier's point of view, a service brand helps profiling the offer and communicating desired product images.

Creating a brand for usership comprises similar measures as in general service brand management. Focussing on the service resources, branding can be obtained by the brand quality of the service-related-products, by choosing a brand name that is distinguishable, relevant, memorable, and flexible, by applying the trademark to all physical evidence of the service according to a coherent corporate identity, etc. The brand identity may further be visualised during the service encounter by uniform clothing of the service personnel. As regards the service results the establishment of a brand can be supported by providing branded gifts and souvenirs or by offering service related products for sale, such as travelling bags sold in train shops. Thereby, customers are enabled to maintain symbolic contact to the service provider and to communicate service consumption towards relevant others.

\section{Conclusions}

The discussion revealed that material goods are part of the social fabric of our lives and that ownership essentially contributes to identity formation and social cohesion in modern societies. Possible ways to recover the symbolic meaning that is 'lost' when giving up ownership of material goods have been sketched. Of course, the discussion is not exhaustive. In particular, the symbolic qualities that are beyond the control and locatory aspects and that are specific to usership need further attention.

\section{Literatur}

Belk, R. W.: Possessions and the extended self. In: Journal of Consumer Research 15, 1988. P. 139-168.

Furby, L.: Possessions in humans: An exploratory study of its meaning and motivation. In: Journal of Social Behaviour and Personality 6, 1978. P. 49-65.

Hunt, J. M./ Kernan, J. B./ Chatterjee, A./ Florsheim, R. A.: Locus of control as a personality correlate of materialism: an empirical note. In: Psychological Reports 67, 1990. P. 1101-1102.

Laverie, D. A./ Kleine, R. E. III/ Schultz Kleine, S.: Reexamination of Kleine Kleine, and Kernan's Social Identity Model of Mundane Consumption: The Mediating Role of the Appraisal Process. In: Journal of Consumer Research 28, 2002. P. 659-669.

Levy, S. J.: Symbols for Sale. In: Harvard Business Review 37, 1959. P. 117. 124.

McCracken, G.: Culture and Consumption. New Approaches to the Symbolic Character of Consumer Goods and Activities. Bloomington and Indianapolis 1988.

Obenberger, R. W./ Brown, S. W.: A Marketing Alternative: Consumer Leasing and Renting. In: Business Horizons. October 1976. P. 82-86.

Schmidt-Bleek, F.: Wieviel Umwelt braucht der Mensch? MIPS - das Maß für ökologisches Wirtschaften. Berlin 1994.

Smith, R/ Houston, M.:Script-Based Evaluation of Satisfaction with Services. In: Berry, L./ Shostak, L./ Upah, G. (Eds.). Marketing of Services. American Marketing Association. Chicago 1983.

Solomon, M. R.: The Role of Products as Social Stimuli. In: Journal of Consumer Research 10, 1983. P. 319-329.

Solomon, M. R.: The value of status and the status of value. In: Holbrook, M. B. (Ed.): Consumer Value. A framework for analysis and research. London, New York 1999. P. 63-84.

I AUTOR + KONTAKT

Gerd Scholl ist Leiter des Forschungsfeldes ökologischer Konsum am Institut für ökologische Wirtschaftsforschung (IÖW) in Berlin. IÖW, Potsdamer Str. 105, 10785 Berlin.

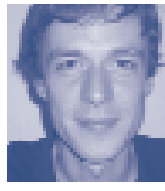
Tel. 030/884594-0, E-Mail: gerd.scholl@ioew.de
Nachhaltigkeit

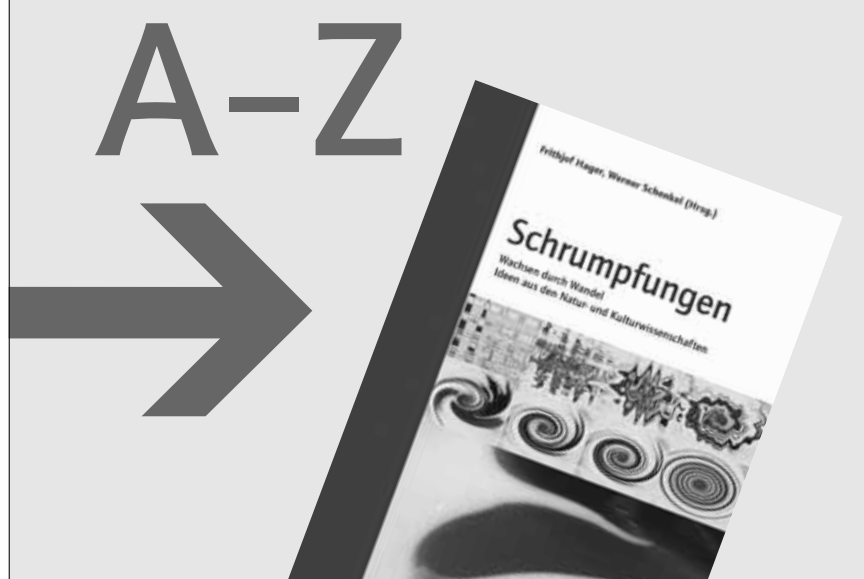

W

Wachstum - wie gerne hören wir dieses Wort. Es ist so positiv, dass wir spontan das Gegenteil nicht eindeutig benennen können. Doch ist alles gut, was wächst? In unserer Wirtschaft besteht ein Zwang zum Wachstum. Wenn etwas schrumpft - der DAX, die Arbeitsplätze, das Einkommen - können wir damit nicht umgehen. Dieses Buch zeigt, wie Veränderungen - auch Schrumpfungen - unser Leben bereichern und andere Perspektiven auf die Wirtschaft eröffnen.

F. Hager, W. Schenkel (Hrsg.)

Schrumpfungen

Wachsen durch Wandel - Ideen aus den Natur- und Kulturwissenschaften oekom verlag, München 2003, 283 Seiten (mit zahlreichen Tabellen und Abbildungen), 22,50 EUR, ISBN 3-928244-95-7

\section{Erhältlich bei}

www.oekom.de

oekom@rhenus.de

$\mathrm{Fax}+49 /(0) 8191 / 970$ 00-405

Die guten Seiten der Zukunft
Ill oekom verlag 
(c) 20I0 Authors; licensee IÖW and oekom verlag. This is an article distributed under the terms of the Creative Commons Attribution Non-Commercial No Derivates License (http://creativecommons.org/licenses/by-nc-nd/3.o/), which permits unrestricted use, distribution, and reproduction in any medium, provided the original work is properly cited. 